\title{
Maleriet og den ny krop - fire nordiske kunstnere 1900-1914
}

Af Niels Kayser Nielsen

Omkring år 1900 sker der et afgørende nybrud i opfattelsen af tid og rum overalt i den vestlige verden. Rummet bliver ekspansivt og udfoldelsespåkaldende; dvs. forum for bevægelse, udstrækning og beherskelse, ligesom tiden bliver en beherskelig og kalkuleret sfære - og ikke kun en væretid. Det er ikke længere nok at være til stede i tid og rum, man må også gøre noget og gøre noget præcist, målrettet og dynamisk med sans for præciseret kvantitet. I Danmark sker denne ændring i løbet af perioden mellem 1873, hvor rigsdaler og skilling bliver til kroner og øre, og 1907, hvor man indfører ti-talssystemet i forhold til rum og flade: man går over til meter og liter, i stedet for fod og alen, potter og tønder. De almue-agtige mål, med deres udgangspunkt i uspecificerede og upræcise kropsmål såsom fod og alen, bliver således afløst af nøjagtigt kvantificérbare mængdeangivelser.

Den ændrede tids- og rumsopfattelse manifesterer sig skarpest $i$ en $\emptyset$ get opmærksomhed på den aktivitet, der forløber i tid og rum. I stort og i småt kommer bevægelsen og evnen til ændring og dynamisk udfoldelse i fokus. Det er tesen i denne artikel, at den ændrede tids- og rumsopfattelse for det første manifesterer sig i en stigende interesse for selve den kropslige bevægelse i tid og rum, herunder den systematiske del i form af sport og idræt. For det andet at den også gør sig gældende i repræsentationen heraf; dvs. såvel i forskningen i idræt, sport og kropskultur som i litteratur og kunst.

Den nye viden om kroppens væren og dens livsrum tolkes på daværende tidspunkt nemlig ikke kun i form af positivistisk videnskab, hvor man kvantificerer og konstaterer, men bliver også formidlet $\mathrm{i}$ andre former for viden end den naturvidenskabelige - fx. kunstens viden. Denne nye kunstviden er med til at sætte aktivitet, vitalitet og kraftudfoldelse i centrum; ikke ved at sætte ord, men ved at sætte billede på. I en livslysten sans for og trang til et særegent paradoks $\mathrm{i}$ form af kobling mellem det konstatérbare og det længselsfuldt villede - hvor rummet mere varsler potentialitet og projekt end reproduktion bidrager kunsten til at fortolke og dermed hjemliggøre den nye opfattelse af dynamik i tid og rum - med idræt og kropsudfoldelse som dels motiv, dels anledning. Kunsten insisterer - via sin billedkraft på at fortroligg øre kropsdynamikken i tid og rum i stedet for - fattigt - at nøjes med den udvendiggjorte tal-abstraktion, der senere i det 20. århundrede gjorde idrætten og kropsdynamikken til et sansetomt og fremmedgjort kvantitetsorgie, der kun havde resultatspændingen som omdrejningspunkt. 


\section{Baggrund}

Den omtalte ændring hænger sammen med en ny årvågenhed overfor omverden, som i sidste instans er materielt betinget.

Sidste fjerdedel af 1800-tallet havde medført en højere levestandard. »Nødvendighedens rige «, dvs. kampen for blot at overleve, var blevet svækket, og tiden var inde til at kere sig om andre og mere sofistikerede dele af tilværelsen. Det fik vidtrækkende konsekvenser. Både kunst og idræt fik nu nye muligheder for at træde i karakter som selvstændige sfærer, der kunne fremtræde som værdifulde i sig selv. Det medførte en begyndende interesse for både »L'art pour l'art« og for dyrkelse af kroppen i sig selv, uden skelen til dens instrumentalisering i form af middel til opnåelse af mål uden for kroppen. Kropskulturen skulle ikke længere være hverken militærets eller pædagogikkens slave.

Der var tale om en civilisatorisk bevægelse, hvor kontrasterne mellem liv og død og - mindre dramatisk - mellem fattigdom og elendighed på den ene side, overflod og spleen på den anden side, blev formindsket, og hvor der tilsvarende blev mere sans for en psykologiserende og sansedyrkende interesse for variationerne og de små detaljer.

Det indebar også en ændret holdning til sanserepertoiret og dets fordeling i forhold til krop, kunst og aktivitet: når der basalt er sørget for kroppens vedligeholdelse, pleje og forplejning, og det kropslige nødvendighedsrige så at sige »kører af sig selv«, er der mulighed for at give sig af med »som om-aktiviteter «. Det indebærer et skift fra de håndgribelige nærsanser, der er knyttet til en pragmatisk omgang med tingene, til clinch med objektverdenen, til synssansen og dermed til tilskuerens visuelle fornøjelser. Denne synssans kan nu oven i købet raffineres i nydelses $\varnothing j e m e d$, for så vidt som den ikke er direkte medansvarlig for livets opretholdelse.

Det er her sport og andre former for kropskultur kommer ind i billedet, nemlig som mimetisk gennemspilning af konflikter, der i modsætning til tidligere løses ved hjælp af ikke-voldelig kropslig adfærd beregnet på afkodning af andre som en visuel fornøjelse. Når et samfund bliver »seriøst « og bliver i stand til at sørge for sig og sine, stiger behovet for sport og mimetisk spænding.

Men det er også her kunsten kommer ind i billedet, for så vidt som man her kan lade kunsten koncentrere sig om motivets maleriske skønhed uden skelen til et ideologisk, religiøst eller mytologisk punkt uden for kunstværket, dvs. et krav om ansvarlighed i forhold til nytte og gavn i henseende til politiske og økonomiske mål. Realisme kan erstattes af skønhedsdyrkelse i sig selv, og med krops- og idrætsfascination er der mulighed for, at dette ikke ender i skøn-ånderi, men bevarer en jordforbindelse i form af en optagethed af kroppens væsen og væren og af kroppens fysiske rum.

\section{Sansningens várblivelse}

I Marie Bregendahls novelle »Sommeraften« i samlingen I de lyse Natter fra 1920 tegnes et fint og nuanceret portræt af et sådant sanseligt bevidsthedsgennembrud hos to pubertetspiger. Dette gennembrud har for det første livshistorisk karakter: de aner, vagt, deres egen sexualitet i det kommende voksenlivs genvordigheder og, lige så vagt, deres egen subjektive identitet. Det tegner på én gang kropsligt besværligt og fascinerende at blive voksen.

For det andet har portrættet historisk karakter: det viser også opbruddet fra en landlig almue-trummerum til en ny og glorværdig industrialiseret verden med 
»gasværk« og »tog«, som hjorddrengen Niels længes så voldsomt efter - han kunne godt tænke sig det helt »vilde«, et sted nede i Tyrkiet. Scenariet med det dragende tog i sommernatten var ikke ualmindeligt i samtiden. Det kendes i billedudgave bl.a. fra Hans Smidts produktion, idet han i 1906 malede denne situation med toget $i$ det fjerne i kontrast til studekøretøjet i forgrunden. Det har karakter af tidsånd og kollektiv mentalitet.

For det tredje har dette opbrud også kropslig karakter, ikke kun fordi pigerne svagt aner deres egen sexualitet og den koglende erotik i omgivelserne, men også fordi de og de andre indbyggere $i$ landsbyen pludseligt skærper deres sanseevne. Sans efter sans vågner: først syn, så lugtesans og hørelse. Denne sanseskærpelse bevirker, at der falder skel fra deres $\varnothing j n e, ~ o g$ at de pludseligt kan »se langt«. Men skærpelsen har i et videre perspektiv også konsekvens på den måde, at almuelivets livløse, daglige trummerum med hjemmeblindhed erstattes af sansen for det ekstraordinære og unikke i deres eget liv. De er på vej til at blive sig selv vár. Der sker en subjektivering.

Denne subjektivering finder sted dels $\mathrm{i}$ relationen: menneske, natur og omgivelser, dels i relationen: menneske, krop og sind, således at novellen i sidste instans bliver en tematisering af en ny - anet - erkendelse af at være kropsligt til stede i verden. Imidlertid er det en væsentlig pointe, at denne erkendelse er vag og ubestemt. De langsomme voksne bønder og deres døtre har vanskeligt ved at sætte ord på deres oplevelse af såvel frygt som fascination af at være til stede i sommernattens trylleri, og da pigerne skal prøve at efterligne den dansende gang hos den unge kvinde, som er på vej til sin kæreste, bliver det i bedste Aakjær-stil til et trallende »singdudelidej«. Så langt og så kort strækker sig deres sprogli- ge gengivelse af den kropslige væren, som de nu er på vej til at erkende. Kropsligheden fremtræder som et på én gang mystisk og dragende under.

På den måde indskriver også Marie Bregendahl sig - omend lidt sent - i den på én gang nysgerrige og frygtsomme fascination af kropsligheden, som er så kendetegnende for de første par tiår af det 20 . århundrede. Sjældent er denne dobbelthed skildret så sart og fintfølende som hos hende, og sjældent er en forfatters klarsyn med hensyn til vanskelighederne ved at sætte ord på kroppen demonstreret så overbevisende som hos hende. Her har ord-kunsten sin begrænsning. Ordenes og sprogets lineære og logiske fremskriden, fra venstre til højre, har svare kvaler med at indfange den kropslige kompleksitet, dens mangel på logik og rationalitet og dens uforudsigelige kontingens. Styrken i hendes novelle er med andre ord at gøre opmærksom på spændingen mellem kroppens væren og den sproglige gengivelse heraf. Hun viser både, hvad sproget kan og ikke kan. Hermed er hun optaget af samme problem, som hendes daværende ægtemand Jeppe Aakjærs lyrik og Johannes V. Jensens forfatterskab også behandler: hvorledes fastholde kroppens og sansernes bevægelse $\mathrm{i}$ formens stivnen? Men ikke kun litteraturen var optaget af dette problem. Det gjaldt også andre af de såkaldte skønne kunster, såsom musik, malerkunst og skulptur. Ikke mindst malerne var optaget af kroppens særegenhed, men også her dukkede der problemer op.

\section{Maleri eller motiv?}

Det er næppe nogen tilfældighed, at kropsfascinationen i begyndelsen af 1900-tallet også tog sig maleriske udtryk. Der er overalt i Norden talrige eksempler på, at både 
kunstnere og videnskabsfolk er optaget af menneskekroppen, dens kapacitet og vitalitet; dermed også billedkunstnerne. Det har de vist altid været, men det særegne i denne fase af malerkunstens historie er den særlige vægt på det nøgne menneskelegeme. Det har altid interesseret malerne. Men det afgørende er, at denne nøgne menneskekrop nu skildres i dynamisk bevægelse i udendørs omgivelser i et regi, der hverken er religiøst eller erotisk domineret. Det er med andre ord kroppen som krop og glæden ved bevægelse for bevægelsens egen skyld, der er i højsædet. Mest udpræget sker det $\mathrm{i}$ form af maleriske fremstillinger af den nøgne mands- og drengekrop i sport og friluftsliv - ofte i forbindelse med vand- og badescener.

Men måske er det slet ikke det »litterært « motiviske, at man vil male idræts- og bevægekroppe, fordi de er nye og interessante, der er det centrale. Måske er det snarere rent maleriske problemer, man er optaget af, problemer som kan løses med kroppen som et mere eller mindre tilfældigt motiv. Givet er det i det mindste, at en lang række malere i de første par tiår af det 20. århundrede er optaget af relationen mellem på den ene side billedets plastiske værdier, dvs. den rumlige opbygning med skikkelsesdannelse, figur og baggrund, og på den anden side farvemæssige problemer, herunder valørproblemer og lysets indvirkning på farvens karakter. Her bød billeder af kroppe i udendørs belysning, dvs. friluftsmaleriet med horisont og sollys, sig til som en mulighed.

Men straks melder sig det næste spørgsmål: hvorfor var det netop kroppe, man tyede til midt $i$ de maleriske problemstillinger? Er det den kunstneriske udfordring, der er på spil, eller er det ønsket om etnologiske folkelivsskildringer? Dette spørgsmål trænger sig i hvert fald på, når man ser på Jens Søndergaards folkelivsbilleder. Søndergaard elskede ringridning, dyrskuer og gymnastikstævner, men i henseende til hans malerkunst virker de trods alt mere som anledning. I en række breve til Poul Uttenreiter fra begyndelsen af 1950'erne skriver han jævnligt om, hvorledes han glædede sig til disse fester, men nærmere besked om, hvorfor de fascinerede ham, får vi ikke, udover at han havde »en hel kasse $\varnothing l$ og en fl Djin osv.« med som proviant - for bedre at kunne se (her cit. fra Zahle 1994: 78). Det maleriske er så selvfølgeligt, at han ikke gider omtale det.

Og her har vi så hans malerier at holde os til. Af dem fremgår det, at det er rytmen og gentagelsen $i$ et derved dynamiseret rum i forening med de små forskelle $\mathrm{i}$ næsten-ensartethed, der optager ham, dvs. nuanceringen. Og så maler han altid disse dynamiske kroppe i et landskab. Det er næppe nogen tilfældighed, for så vidt som det giver ham mulighed for at stedfæste aktiviteterne. De skal ikke placeres i et abstrakt tomrum. Kroppene er et værn mod den abstraktion og akademiske spekulation, som Søndergaard aldrig kunne lide, aldrig gav sig af med og aldrig kunne forstå.

Resultatet bliver en treklang bestående af malerens dobbeltblik for billedets selvstændige logik og bevægelsesmotivets strukturer i samspil med landskabet som den tredje faktor. Her bidrager den landskabelige jordbundethed til at holde balancen. Den er nemlig ikke så ligetil: for megen billedmæssig logik afgiver for meget præg af stil, smag og fermt greb og leder nemt til indholdstom tørhed og stilistisk egenværdi, der kun har det preciøse og dekorative for $\varnothing j \mathrm{je}$, medens omvendt for megen motivisk gengivelse rummer fare for koncept- og idéillustration, således at man svigter det billedmæssige og nøjes med at gengive og afspejle. 
Hos Søndergaard løses dette problem raffineret ved, at han opsøger motiver, som i sig selv rummer maleriske muligheder: vand, strand og krop. Her kan han lade sine billeder folde sig ud i spændingen mellem det lokale og det universelle, mellem empiri og kosmos, mellem primitivisme og forfinelse, som det hedder om en af hans åndsbeslægtede, den finske Gallén-Kallela (Laugesen 1992: 22). Men det havde andre malere gjort før ham; rundt omkring i Norden i tiden op til 1. verdenskrig.

Det er denne interesse for menneskekroppen i sport og friluftsliv, der skal kastes et blik på her. Hvorledes fremstilles menneskekroppen? Hvilken kropsopfattelse ligger til grund? Hvad er det, man fascineres af? Det er nogle af de spørgsmål, der skal besvares i det følgende. Det sker ud fra den grundopfattelse, at såvel kropssom rumsopfattelsen i denne periode undergår en forvandling og er stedt i opbrud, samt at dette opbrud genfindes $\mathrm{i}$ alle de nordiske lande, i lighed og forskellighed. Der vil således også blive lagt vægt på en komparativ belysning af fænomenet.

\section{Hverdagenes kropsaristokrater}

I den forbindelse er det ikke uinteressant at se på, hvad det er, disse samtidens malere hæfter sig ved. Ét indblik heri får man i den finlandssvenske arkitekt, kunstskribent og -samler Sigurd Frosterus' betragtninger i bogen Olikartade skönhetsvärden fra 1915. Bogen er en rapsodi af rejseindtryk fra Europa og rummer bidrag skrevet helt tilbage fra de første år efter 1900, hvor han gik i gang med at behandle den samtidige udenlandske kunst i kulturtidsskriftet Euterpe, idet han havde fået færten af såvel et kunstnerisk som et rummæssigt opbrud.
Et af de steder Frosterus skildrer er Siena. En af pointerne i denne skildring er bestræbelsen på at vise forholdet mellem natur og kunst (i dette tilfælde arkitektur), hvor det tydeligvis er efterstræbelsesværdigt, at der er balance mellem disse to størrelser, der ellers rummer fare for at ende i en dikotomisk modsætning.

Men det er lige så tydeligt, at Frosterus i ønsket om at skele til naturen, når man har med kunst at gøre, samtidig er fascineret af en ren kunstnerisk orden. »Siena bör ses om vintern «, skriver han

»medan luften är klar och kall och ren, då konturerna stå fasta och hårda som dragna med grova tuschsträck och färgerna, utan lasurer, utan övergånger, bryta sig skarpt mot varandra såsom hos glasmosaiker infattade i bly« (Frosterus 1915: 13).

Senere bruger han adjektiver som »enhetligt, strängt, stiliserat«. Ingen landlig idyl med romantik og krumme, bløde linjer her. Idealet er ikke til at tage fejl af: »Ett övermått av spänstighet ligger bunden inom enkla murar« (Frosterus 1915: 20).

Kontrolleret kraft og vitalitet er tidens løsen - med skyldig hensyntagen til ånd og sjæl. Stilen er aristokratisk og har sans for det nytteløse overskud, ornament og idræt for sjovs skyld følges her smukt ad, som når han begejstret skriver om lawn tennis som en ædel sport, og som en aktivitet »vår plebejiska tid « næppe har sans for. Han er imponeret af verdensmesteren A. F. Wilding, der spiller tennis, som han spiller billard:

»Skenbart långsamma, noga beräknande och övervägda rörelser. Ingen nervös brådska, ingen livfull iver. Ingenting för en tom effekt. När han dödar en boll gör 
han det lekande lätt, som vore det det enda naturliga, det enda möjliga «(Frosterus 1915: 286).

Igen: kontrol og sans for det formålstjenlige i forhold til selve den sports-kunstneriske akt - og lige dele afstandtagen fra tom pragt på den ene side og pågående pragmatik med borgerlig snusfornuft i forhold til hverdagens travle gøremål på den anden side. Frosterus langer voldsomt ud efter de tyske middelalderbyer, hvis indbyggere, $\mathrm{i}$ hans øjne, altid har været kuede under skråvæsenets og en bondesnu nyttetænknings åg (Frosterus 1915: 27).

Det er det ånds- og kropsaristokratiske selvbevidste individ, hævet over dagligdag og trummerum med længsel efter en renere og mere storslået verden, der her taler. Han taler om et ekstraordinært univers, hvor det sociale står i skyggen af det kunstneriske og kulturelle. Han søger en verden hvor skønheden - forstået som foreningen af fast fond og bevægelse for bevægelsens egen skyld - er i højsædet. Intet under, at han andetsteds i bogen citerer den i samtiden så populære »Midnatssang « fra Nietzsches Zarathustra:

\section{»Die Welt ist tief}

und tiefer als der Tag gedacht «

Denne passus handler om det overskud, der nok er $a f$ denne verden, men ikke $i$ den. Den havde bud til mange kunstnere, malere og forfattere, der brugte den som omdrejningspunkt i deres $\emptyset$ nske om at overkomme og tilsidesætte hverdagenes synlige sammensurium af smålighed og snusfornuft - samtidig med at man også ville tage del i hverdagene med deres sanselige gøremål. I sidste instans var målet at pumpe hverdagslivet med ny energi og storslåethed. Det er - som hos Marie Bregen- dahl - banaliteten og det livløse i hverdagen mere end hverdagen i sig selv, man går til angreb på. Man vil ikke nøjes, men føler sig også forpligtet. Sigtet er nok aristokratisk - men formålet er, paradoksalt, at det aristokratiske skal blive demokratisk og folkeligt.

På den måde er Frosterus - der betragtes som en af forløberne for den funktionalisme og kulturradikalisme, som i Finland havde et længere tilløb end i de $\varnothing$ vrige nordiske lande (Kayser Nielsen 1997) - også det nye, unge og optimistiske århundredes mand. I et brev til moderen fra 1904 skriver han om mødet med storbyen Berlin, at han havde følelsen af, at der faldt skel fra hans øjne, og at »nya värden plötsligt stega fram, det var som ett vaknande ur en dröm till en rikare och lifvande verklighet « (Cit. fra Kasvio 1992: 31).

Det måtte også få kunstneriske konsekvenser. I et andet brev til moderen fra 1906 skriver han:

»Den framtida konsten skall lära sig metoden att med vakna ögon se sig omkring«(Cit. fra Kasvio 1992: 32).

Det er som at høre en anden stor opvågner, Johannes V. Jensen, fra samme tid. Også han ville se sig omkring og se sig for. For at blive klogere.

30 år efter bogen Olikartade skönhetsvärden skriver Sigurd Frosterus da også begejstret om sin sjælsfrænde Johannes V. Jensen og hans fascination af de københavnske cykelpiger, inkarneret i kontorpigen Gudrun »som uttryck för den fredliga evolutionen; ett sorglöst välstånd ett stycke ovan svältgränsen « (Frosterus 1946: 85). I sin frejdige fremfærd $\gg \mathrm{i}$ gatstråkens trafikström på väg till arbetet och vid fritid till badstrand eller bokskog « bliver Gudrun et symbol på både civilisationens frem- 
skridt og kropslighedens kommen til sin ret. Hun er - set med denne optik fra tiden før 1. verdenskrig - en hverdagslivets anonyme aristokrat.

Det er drømmen om denne aristokratiske krops- og sjælsskønhed, der var det centrale for de samtidskritiske malere og litterater, der ikke kunne stille sig tilfreds med blot et socialt fremskridt. Kropslig dannelse var for dem ikke lig med mad på bordet; man skulle også kunne lide at bade i sollys - og være god til tennis.

\section{Edvard Munch og de poserende bademand}

Det kan næppe undre, at Sigurd Frosterus også kastede sig over Edvard Munch og hans sanseevangeliske og Nietzsche-inspirerede fascination af kroppen og kropslighedens løsninger på Vesterlandets »sygdom til døde«. Der tænkes her på Munchs Warnemünde-gennembrud sommeren 1907, hvor han syg i sjæl og sind af både forfølgelsesvanvid og et alt for stort alkoholforbrug søgte trøst i Nietzsches Zarathustraord om, at man i stedet for at lytte til sig selv skal lytte til sin krop (dengang var det ikke en inflatorisk kliché). Derfor malede han livsduelige nøgne mænd, der gule af solens farver og røde i ansigterne stiger op af det blå og grønne hav med bredbenede skridt.

Frosterus omtaler dette som et vendepunkt i Munchs kunst; hans bestræbelse er at gøre sig fri af selvoptagethedens malstrøm. Munch bliver sol-dyrker, og dissonanserne løser sig i svalere, mere klangskønne akkorder, skriver Frosterus (Frosterus 1946: 39). Ragna Stang er inde på samme tanke, når hun hævder, at Munch her ville arbejde sig ud af selvcentreringens spændetrøje. Han ville være lige så vital som de nøgne, kraftfulde mænd, han malede (Stang 1978: 197).

Sagt på en anden måde: Tysklands-periodens billeder markerer ikke, hvad Munch som ekspressionistisk maler erindrer, men hvad han ser. Øjnene er på vid gab, og det introspektive er (for en stund) suspenderet. Samtidig viser denne periode om noget, at der ikke er hold i den ellers hævdvundne opfattelse, at Munch i det store og hele malede sit eget liv som en efterrationaliserende, indadvendt og psykologiserende malerisk gestus. Her ser man, som den nyeste Munch-forskning og -udstillingsvirksomhed gør gældende, at han også havde et lysvågent blik for de spørgsmål af almenkulturel karakter i samtiden, som rejste sig for en intellektuelt og internationalt vågen kunstner.

Noget om snakken er der givetvis, når man iagttager fotografiet af Munch på stranden i Warnemünde fra samme sommer. Han er her vist poserende i djærv mandighed med stolt skrævende ben, korte badebenklæder og pensel $i$ hånd; med en nøgen mandsmodel i baggrunden og maleriet lige bagved. I al sin konstruerede og opstillede mandhaftighed viser fotografiet Munch i en overgangssituation, hvor det er svært at trække grænsen mellem kunstneren og friluftsmennesket. De sjælelige kriser bestræber han sig voldsomt for at lægge bag sig for i stedet at hellige sig friluftslivets stærke simpelhed og sunde enkelhed i solbeskinnet driftighed.

I både den udgave af billedet Badende maend fra 1911, der hænger i Munch-museet i Oslo, og i 1907-udgaven, der findes i Atheneum i Helsingfors, har Munchs vand-aristokrater de rødglinsende ben solidt plantet på jorden. Nærmere bestemt betræder de selvsikkert og vertikalt frembrusende den varme, solbeskinnede strandbred, medens deres hoveder flugter med 
det blå hav ude i horisonten. Det er som, holder de hovedet højt, men også koldt, midt i deres djærve gåpåmod. Nok livstørst og vitalitet, men med fatning og kontrol. Kraft uden amokløb. De kolde hoveder giver mændene et vist køligt og kynisk anmasende præg. De virker ikke rare og omgængelige, disse mænd. De minder om Vigelands »Kraft durch Freude«-personer.

Deres mørke ansigter, hvor den ene bærer skæg, har parallelitet i skridtet, hvor behåringen er angivet, såvel som mandslemmet. Alligevel er det ikke dyriske hanner, men civiliserede maskuline livsdyrkere i enkel nøgenhed, der her er portrætteret, men kønnet angiver, at vi er trods alt er i biologismens århundrede, hvor det biologiske skal forenes med det sociale. På dette tidspunkt mente man med det sociale, begrebshistorisk, både historie, samfundsvidenskab, og - så småt - biologi (Liedman 1997: 53 ff.). Men samtidigt er det tydeligvis ikke det nøgne menneske, men den voksne, nøgne mand der erobrer livet, som er idealet. Dvs. et kulturaliseret nøgent menneske.

Samtiden reagerede voldsomt på dette utilslørede portræt af Munchs selvbevidste lemmedaskere. Om efteråret 1907 blev billedet nægtet udstilling i Clematis kunsthandel i Hamburg, idet man frygtede en politianmeldelse af en så direkte hyldest til manddommen (Eggum 1983: 217).

I 1918 tog Munch imidlertid atter temaet op i billedet Badende Mand. Denne gang er det mindre en apoteose til den nøgne mandskrop. Snarere drejer det sig om det naturindfældede menneske, hvor mandekroppens muskler solbelyste reflekteres i og reflekterer lyset og vandet. De cirkulære, næsten kubisme-foregribende linjer i mandekroppen modsvares af linjeføringen i klippelandskabet i baggrunden og strandens sten i forgrunden. Vitalismen er her, fordi den ikke er knyttet til selve kroppens, men til det generelle legemes virkning, mindre kraftfuld og anstrengt og mere blødgjort end i de tidligere bade-billeder. Samtidig er det rent maleriske blevet vigtigere end det villede og ideologiske. Den proklamatoriske fanden-i-voldskhed er nedtonet til fordel for afsøgning af farvemæssige problemer. Uheldigvis er det gået ud over kvaliteten.

De første badebilleder fremtræder trods deres manglende orientering mod det maleriske - som bedre og mere helst $\varnothing$ bte malerier. De er med deres lyse og rå farver mere ferske og karske i al deres djærvhed. Den nok så iscenesatte kombination af friluftsmand og kunstner havde sine fordele, måske fordi den så evident, men også nyskabende, centrerede sig omkring det markerede og vedgået kunstfærdige. Men også disse billeder havde deres svagheder. Svagheden er, at man kammer over: billedet er villet. Munch har her lyttet for meget til tidsånden. Han har lavet et malerisk flot billede, men det emmer og syder af villethed, midt i det malerisk vellykkede. Balancen lykkes ikke. Den produktive spænding, der ellers altid giver Munchs billeder kraft, er her degraderet til fidel tidsånds-venlighed - midt $i$ al trodsighed: her vil han for meget.

\section{Magnus Enckell og de rene farver}

Munch var ikke den eneste, som malede strand og nøgne mennesker i disse år. Der er ovenfor peget på Sigurd Frosterus, som en katalysator for et nyt, solbeskinnet virkelighedssyn i den finske kunstdebat. Frosterus forsøgte sig også selv med nogle strandakvareller fra Lido i Italien, da han i foråret 1906 var på ferie dér, men vist mest 


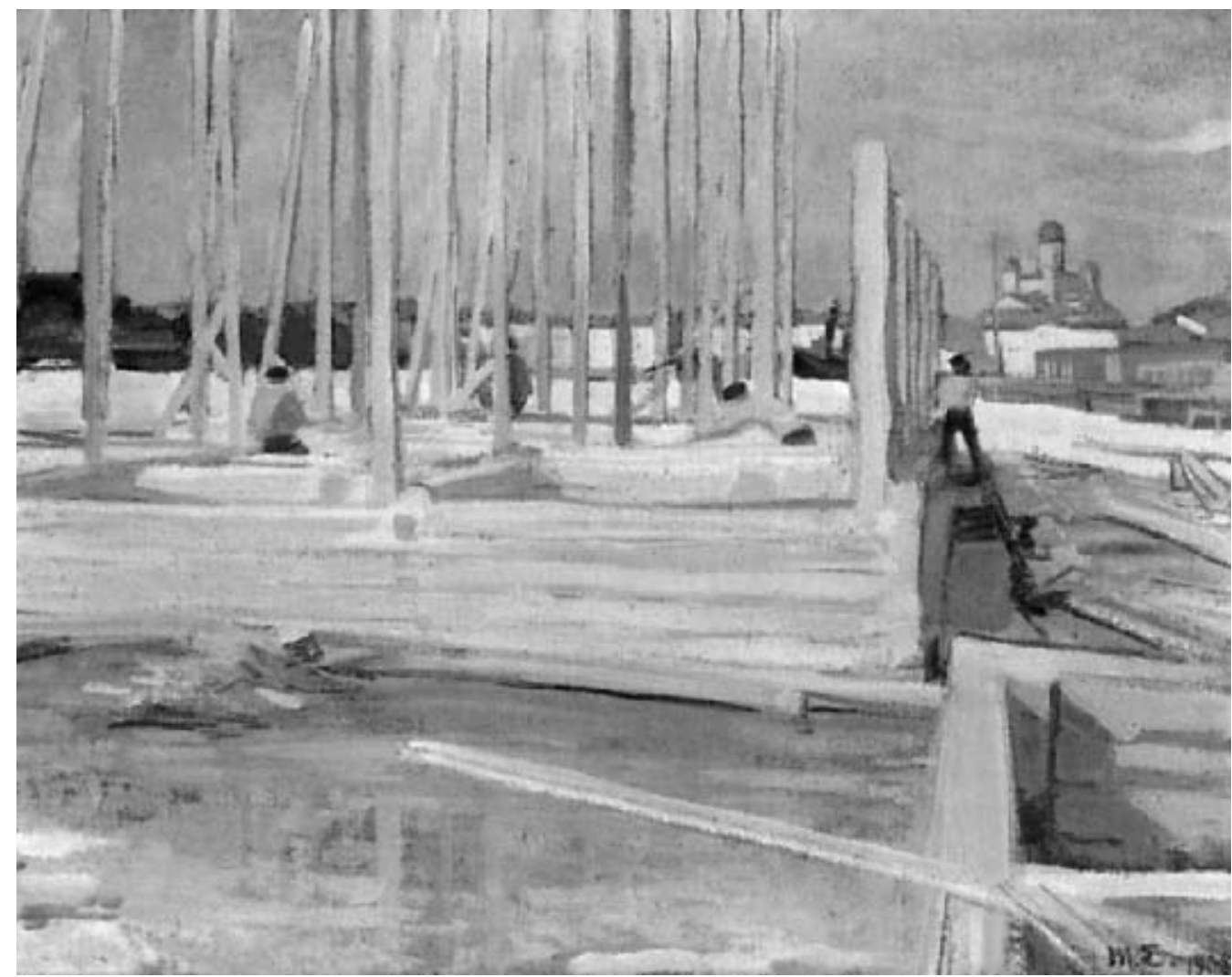

Magnus Enckell, Silta-arkkuja Katajanokalla/Brokistor, Skatudden 1908.

på skrømt. »Jag gör det för mitt eget nöjes skull, för att skärpa mitt öga«, skriver han hjem.

Den, som indløste Frosterus' program i malerisk henseende, blev i stedet Magnus Enckell. Allerede 1908 havde han dels i olie, dels i akvarel malet en serie lys- og luft-billeder fra havnen i Helsingfors med et blændende skarpt og køligt lys ind mod byens »waterfront«. Med den blå himmel som kontrast stråler de af en kølig og kontrolleret sanseglæde. Billederne er tydeligtvis impressionistisk påvirkede, men rummer samtidig en egen nordisk melankoli, der relativerer den rent tekniske dygtighed, som ellers imponerer med en sart farvebeherskelse og en stram organisering af motivets billedmæssige muligheder. Samtidig er billederne »sande «: den, der har oplevet både forårslyset og den brændevinsskarpe efterårsluft i Helsingfors, ved, at Enckell ikke forsynder sig mod realismen midt i den artistiske pragt. En halv snes år senere er den impressionistiske forårssarthed afløst af mere frodige og romantiske, ekspresionistisk prægede malerier. Enckells farveskala er blevet mørkere.

Mellem disse to perioder ligger der en overgangsfase, og ligesom Munch maler også Magnus Enckell nøgne mennesker ved stranden i sin overgangsperiode. Det sker i den periode, der er blevet betegnet som den lyseste overhovedet i finsk maler- 
kunst, nemlig årene 1910-12. I disse år maler Enckell sine friluftsbilleder af nøgne mennesker på grænsen mellem land og vand, herunder oliemaleriet Gossar på stranden og den lille skitse Från Hogland, der måske er Enckells allerbedste fra disse år. Her på øen midt ude i Den finske Bugt viser Enckell, med bibeholdelse af den lyriske finhed fra havnemotiverne et par år tidligere, en ferskhed og en vitalistisk sanselighed, som det ikke siden lykkedes ham at overgå. Sollyset hamrer ned over stranden og ind i beskueren. Det er rå vitalisme - blottet for kosmiske og naturevangeliske overtoner - med mennesker, der simpelthen er glade for at være til. Samtidig foregriber ikke mindst Gossar på stranden hans ekspressioniske, tungere farveskala. Blåt, rosa, lilla, grønt, rødt og gult, hvor den ene af drengene er knaldende rød, medens den anden har en blågrøn overkrop i genskæret fra lyset, medens ansigt og ben farves rødt.

Det mest karakteristiske træk er dog farverenheden. Billedet er mere malerisk end litterært. Vitalismen er tydelig nok, men den er funderet i kunstneriske problemstillinger. Ganske vist skal der fortælles om friluftsglæde og drengedynamik, men først og fremmest er det bestræbelsen på at undgå farveovergange og at fremvise den rene palet, der er påfaldende. Farverne spændes hårdt op mod hinanden i et ublandet spektrum. Ren, lysende farveklang er målet, men også - bevares - midlet, når motivet nu er raske drenge, stenhårde klippeblokke og blændende sensommerlys hen på eftermiddagen, når skyggerne bliver lange.

Måske er det netop, fordi Enckell er så ligeglad med det litterære, dvs. at han giver pokker i det villede, at han er i stand til at skildre det vitale: han glemmer ordene og grammatikken og satser mere på erfaringsssprog end på videnssprog.
Den sjælelige efterklang og selv-analyserende poseur, som, trods alt, prægede Munchs billeder fra samme år, er pist væk hos Enckell. Her er der mere krop og ubekymrede drengestreger end hårdt tilkæmpet manddom. Enckells drenge har tilsyneladende spist rugbrød alle deres sorgløse dage, medens Munch og hans mænd synes først lige at være begyndt. Som Jacob Paludan skriver om Thomas Manns lille roman Tonio Krøger med scener fra badelivet ved Aalsgårde og Tonios forelskelse i den lysblonde lægedatter Inge Holm:

"Den fortryller, som Fremmedes Blik paa vore overbeskrevne Lokaliteter kan gøre det, den har et Hjerteslag, som ikke er almindeligt hos den analyserende Forfatter. Lad mig kigge $i$ den, naar Kvalmen ved altfor mange trykte Ting foles lige om Hjørnet. Den har Brisen, Septemberlys, «C-Dur. (Paludan s. 5-6).

Det samme gælder Enckells badedrenge. Også de er befriet for tidens og menneskehedens evige problemer. Man kan ikke engang sige, at de nyder livet; de er simpelthen livet - placerede $i$ et rum mellem det lokale og det kosmiske er de i deres es, dvs. »esse«, der som bekendt på latin betyder væren.

\section{J.F. Willumsen, betydningen og det kosmiske}

Hos Enckell er det kosmiske nedtonet til fordel for karskheden og friskheden i selve bevægelsen og livsudfoldelsen. Hos Willumsen er det omvendt. Og endda i stigende grad, som årene gik. Medens Enckell forlod de strandglade børn og de nøgne kroppe, nærede Willumsen en livslang in- 
teresse herfor, omend de nøgne mennesker fra hans sene periodes produktion i højere grad har symbolsk og måske dybdepsykologisk betydning (Buurgaard 1997). Dem ses der derfor bort fra i denne sammenhæng.

I stedet skal vi se nærmere på de badebilleder, som Willumsen producerede i samme periode som de $\varnothing$ vrige kunstnere, vi her tager op, dvs. i årene mellem 1900 og 1914. Alene her er der nok at tage fat i. Willumsen tager del i datidens store interesse for kroppen, men gør det på sin egen, dynamiske facon. Hos ham er det maleriske mere afgørende end motivet. Kroppen og dens bevægelse interesserer mest af alt som form:

"Hovedsagen er Böjningen af Kroppen, Lemmerne og Fingrene. Hovedets Hoeldning, Muskulaturens Karakter (Krogh 1987: 22).

skriver han 15. jan. 1899 til Alice Bloch, en kunstinteresseret veninde, tidligere gift med kunsthistorikeren Emil Hannover.

Takket være brevene til hende har vi også mulighed for at kikke Willumsen nærmere i kortene vedr. hans portrætter af badende børn. Studierne hertil påbegynder han i 1902, hvor han er i Amalfi sammen med sin elskerinde og senere hustru Edith. Han kan ikke fordrage at være der. Italierne er noget pak, skriver han hjem:

„Varre Rak, Svin, Snydere gives der neppe paa Jorden. Her er umuligt at bo $i$ langere Tid. Det er Folk paa laveste Trin. For 300 Aar siden har her varet en Tid hvor der var Velstand og Sans for Skфnhed. I de store Paladser med Vaabnet $i$ Porthvalvingen er nu Rakket rykket ind og sviner og snadrer, uden Evne til blot at vedligeholde det de modtog i Arv fra Forfcedrene. De tér sig som Hunde og gør deres Forn $\phi$ denheder paa Trappegang og midt paa Gaden. Ved højlys Dag. De er paa alle Punkter degenererede ...«(Krogh 1987: 28-29).

Det er således hverken den ædle vilde eller det pittoreskt eksotiske Willumsen ser i Syditalien. Hans ærinde er da heller ikke hverken salonkunst med osteria-scener eller trommesalsbilleder af danske kunstnerkolonier. Det er det nøgne menneskelegemes mange former og udtryk, han opsøger. Og måske endda slet ikke kroppens former og bevægelser, men snarere de forskellige former og bevægelser som i det hele taget kan produceres, i dette tilfælde af en krop. De italienske drenge får penge for at stå model på stranden. 10 øre for at stå på ét ben og holde i sin strømpe på den anden fod, medens Willumsen fotograferer (Krogh 1995: 81 ff.). Resultatet blev en stribe af fotografier taget dels i 1902, dels i 1904, hvor Willumsen vendte tilbage. Samme år, i august, rejste han videre til Bretagnes sydkyst, idet havet og stranden i Syditalien ikke kunne tilfredsstille hans $\varnothing$ nske om at indfange den rytmiske serie af lange rullende bølger på en bred og bar strand. Willumsen gik systematisk til værks i sin videbegærlighed efter form og udtryks overensstemmelse.

Resultatet af anstrengelserne kom allerede i 1904, hvor han laver en skitse i olie med titlen Badende børn. Det endelige resultat lod dog vente på sig og kom først nogle år senere. I form af henholdsvis det store billede med titlen Badende børn på Skagens Strand, som han arbejdede på i Skagen sommeren 1909, og den endelige version med titlen Sol og ungdom. Børn på stranden fra 1910, der i dag pryder en endevæg i en af salene i Göteborgs Kunstmuseum. I forhold til forlægget fra 1904 er 


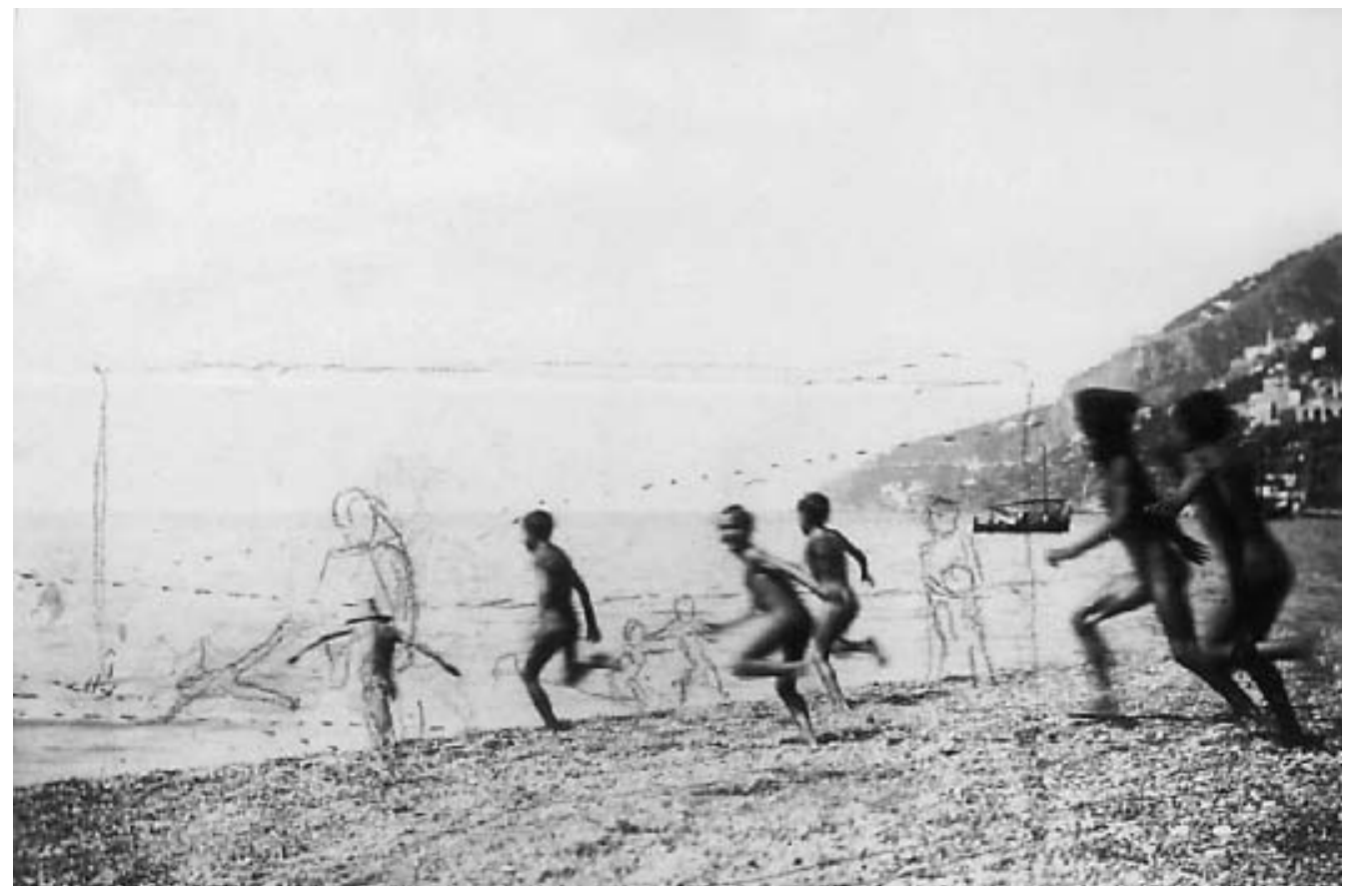

Seks løbende drenge på stranden ved Amalfi, 1902 eller 1904. Fotografi med blyantstegning.

det tydeligt at se, hvorledes der sker en forskydning bort fra det maritime i retning af kombinationen menneske og hav. I 1904udgaven ser man ganske vist en 4-5 badende skikkelser ude i havet, men det er dog mest af alt et marinemaleri. Hvor anderledes er da ikke de to, næsten identiske 1909- og 1910-udgaver. Her er vi meget tættere på både hav og mennesker.

Kompositorisk er billedet bygget op over kontrasten mellem på den ene side havets og strandlinjens uendelighed $\mathrm{i}$ både længde og bredde og på den anden side nærheden i form af de mange børn, der er på vej ud i vandet. Som han påpegede allerede i 1899 i det ovenfor citerede brev til Alice Bloch, er det harmonien mellem helhed og detalje, som er afgørende. I Sol og ungdom har dette par karakter af havets og vandets al-tid og øjeblikkets badende nu- tid. Samtidig med at hvert eneste af børnene er indfanget $i$ hver sin fase af et rytmisk løb. Som senere Jens Søndergaard i hans ringriderbilleder er det spændstighedens og hver eneste bevægelsesfases enestående og særegne form som deludførelse af en samlet bevægelse, der interesserer. Willumsen er her en slags bevægelsesanalytiker, men en kunstnerisk sådan; for det rent biologiske og kliniske har han mindre blik for end den samlede bevægelse, som han så til gengæld piller fra hinanden i analytisk øjemed for at undersøge dens rent maleriske muligheder. At det rent maleriske er i højsædet fremgår af hans møjsommelige arbejde med kontrastvirkningen i form af fordelingen i farvemæssig henseende af lys og skygge på dels børnenes kroppe, dels vandoverfladen og sandet.

Mere end hos nogen anden af hans kol- 


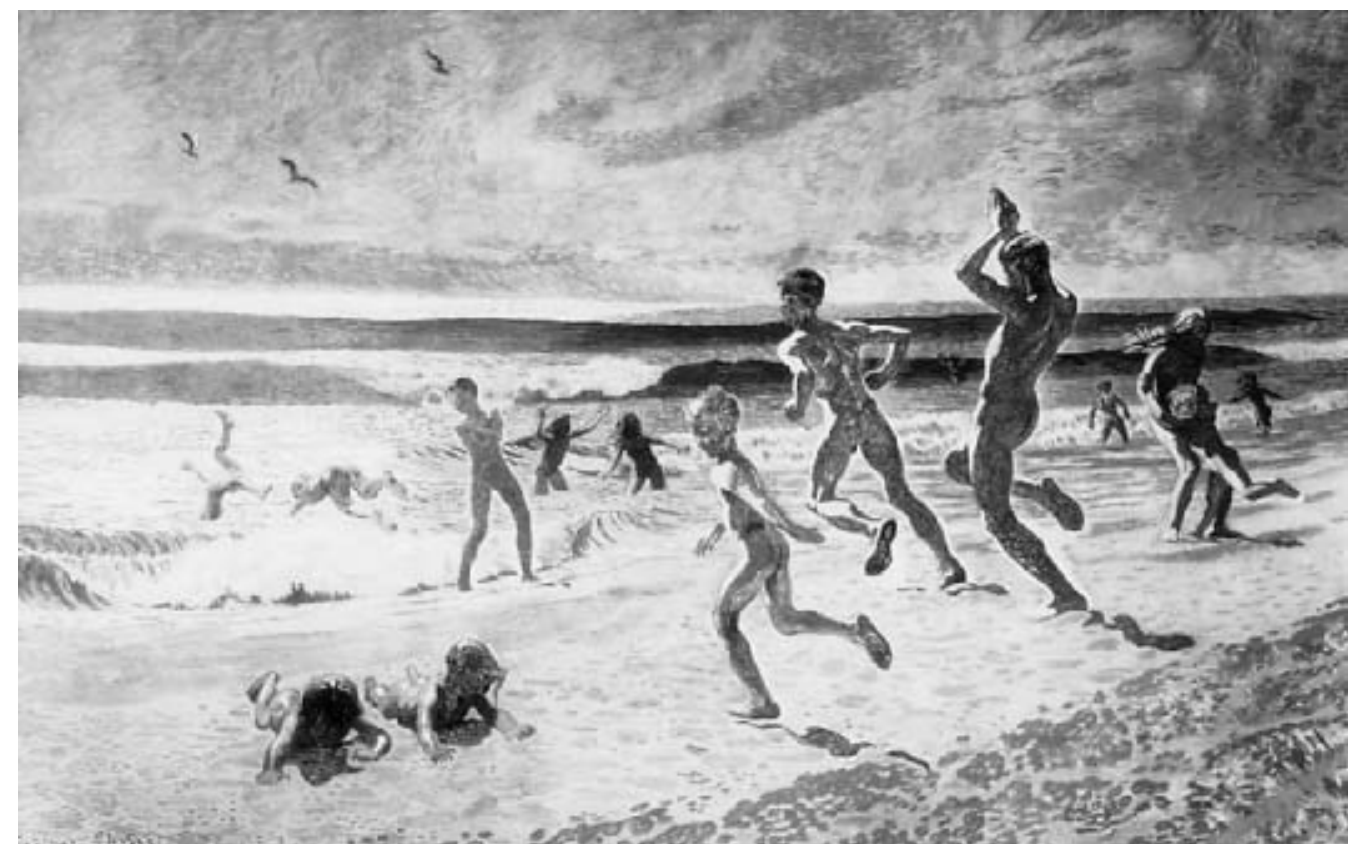

Badende børn på Skagens Strand. Generalprøve. 1909. Olie på larred. $265 \times 425 \mathrm{~cm}$ (deponeret af Skagens Museum).

leger i samtiden er det da menneskekroppen placeret $\mathrm{i}$ et rum, der optager ham, hvor menneskekroppens finale karakter og evne til at skabe unikke øjeblikke kontrasteres af havets rytmiske brænding med dens evigt gentagne bevægelse. Sol og ungdom har nok karakter af et naturbillede, men som altid hos Willumsen er denne natur befolket. Det er med andre ord menneskekroppens evne til at sætte præg på naturen og dens evne til - via kontrast - at lade naturen komme til sin ret, der er i søgelyset. Således er der i sidste instans tale om en raffineret leg med og afsøgning af det inderligt kulturelle spørgsmål om betydningens skabelse i relationen mellem forskel og lighed. Willumsen er ikke harperomantiker, han er kunst-maler. Hos ham mere end nogen anden ser vi spændingen mellem kroppen som anledning og glæden ved kroppens egenfærdighed. Her er spændin- gen mellem motivet og det maleriske trukket så hårdt op, som det var muligt på den tid.

I kraft af denne interesse for betydning og menings forudsætninger kan det næppe overraske, at Willumsen også måtte nære en næsten panisk skræk for den natur, der »bare « er i al sin kosmologiske stumhed og uigennemtrængelige tavshed. Denne naturens »meningsløshed « symboliseres hos ham af solen som den altopslugende og fortærende kraft, der i sin intet-sigende grusomhed knuser mennesker, sådan som vi ser det tematiseret i Efter stormen fra 1905 og endnu værre i det grufulde maleri i olie og tempera fra 1916 med titlen $\mathrm{Na}$ turskrak. Efter stormen 2. De står begge i skarpeste kontrast til den afvejning af natur og kultur, forskel og lighed, som kommer til udtryk dels i badebillederne fra århundredets første årti, dels i En bjergbestiger- 
ske fra 1914. Her er dikotomien ikke dødelig, men produktiv.

Willumsen blev i samtiden bebrejdet, at Sol og Ungdom manglede stemning. I den forbindelse tog Willumsen til genmæle og sagde, at det ikke var hans mening at male stemninger, for så vidt som man herved forstod noget vagt og hendøende $\mathrm{i} »$ halvbelysning «, dvs. en aftenstemning.

»Hvorfor er der ikke noget, der hedder Dagstemning? Har ikke også den strålende Sol, det friske Hav og de nøgne børn en Stemning over sig?"

spurgte han retorisk (Moltesen 1923: 28). For ham var formklarheden og de klare farver som middel til gengivelse af lys livsfylde en lige så legitim stemning som fin de siècle-maleriets vemodigheder i 1890'erne.

\section{Eugène Janssons fristelser}

Medens de malere, vi hidtil har beskæftiget os med, har malet udendørs kropsaktiviter, der ikke har stået i sportens tegn i snæver forstand, men mere har haft karakter af friluftsliv, er dette ikke tilfældet hos svenskeren Eugène Jansson. Hos ham rykker vi både indendørs og ser på egentligt sportiv idrætsudøvelse. Det kan umiddelbart virke ejendommeligt, for så vidt som Jansson givetvis også - i sin tidligere kunstneriske praksis - har været den mest melankolske og lyriske af de omtalte malere. Det er ikke for ingenting han er blevet kaldt »den blå bys maler «, idet hans tidligste værker var malet i den elegiske 1890'er-stil, som bl. a. Prins Eugen stod som repræsentant for og promoverede. Så tæt på hinanden var de to malere, konges $ø$ nnen og den fattige faderløse fra Söders arbejderkvarter, at kunstnervennerne kaldte Eugène Jansson »foto- gen « for at skelne dem fra hinanden. Det skyldtes nu også, at Jansson spædede sine farver ud med petroleum og terpentinolie (Zachau 1998: 37).

Denne elegiske malerkunst, med en troldsk blå farvesætning og en lang række vuer ud over Stockholms blå vande, knyttede sig til det nationalromantiske maleri, som florerede i 1890 'erne i Sverige. Her dyrkede man det tungsindige og vemodige, ofte med motiver fra aften- og nattetide. Det er et skumringsmaleri med dunkle pasteller og udviskede konturer lagt an på stemningsgengivelser, hvor beskuerens blik skal føres dybere og dybere ind i billedets blålige mystik. Som Henrik Cornell gør opmærksom på i sin bog om den svenske kunsts historie, er det vigtigt for Jansson i denne fase af sin kunstneriske virke at lægge afstand til det i tid og rum nærliggende (Cornell 1959: 222). Af den grund er forgrunden i hans billeder, som oftest placerede nederst i billedet, tomme. De udgør den verden, hvorfra vi flygter og længes bort ind i den symbolsk anede fjerne horisont. Vi ser et romantiserende, »dybt « maleri med en æstetiserende livsholdning, der hører hjemme i kunstens drømmeverden. Den har måske også taget farve af Janssons egen svagelighed som barn (ligesom Munch) og hans yderst fattige levevilkår som ungt menneske.

Og så kommer gennembruddet, nærmere bestemt i årene omkring 1905. Han skifter både farve og motivkreds. Det sker næppe af nogen tilfældighed. Dels er det under indtryk fra tidsåndens idræts- og sportsbegejstring, dels som følge af Janssons egen interesse i idræt og kropsøvelser (Zachau 1998: 40). Lige siden han som 13årig blev ramt af skarlagensfeber, havde han anvendt idrætten som led i en hård fysisk genoptræning, der var så hård en kost, at den i perioder var ved at tage livet af 


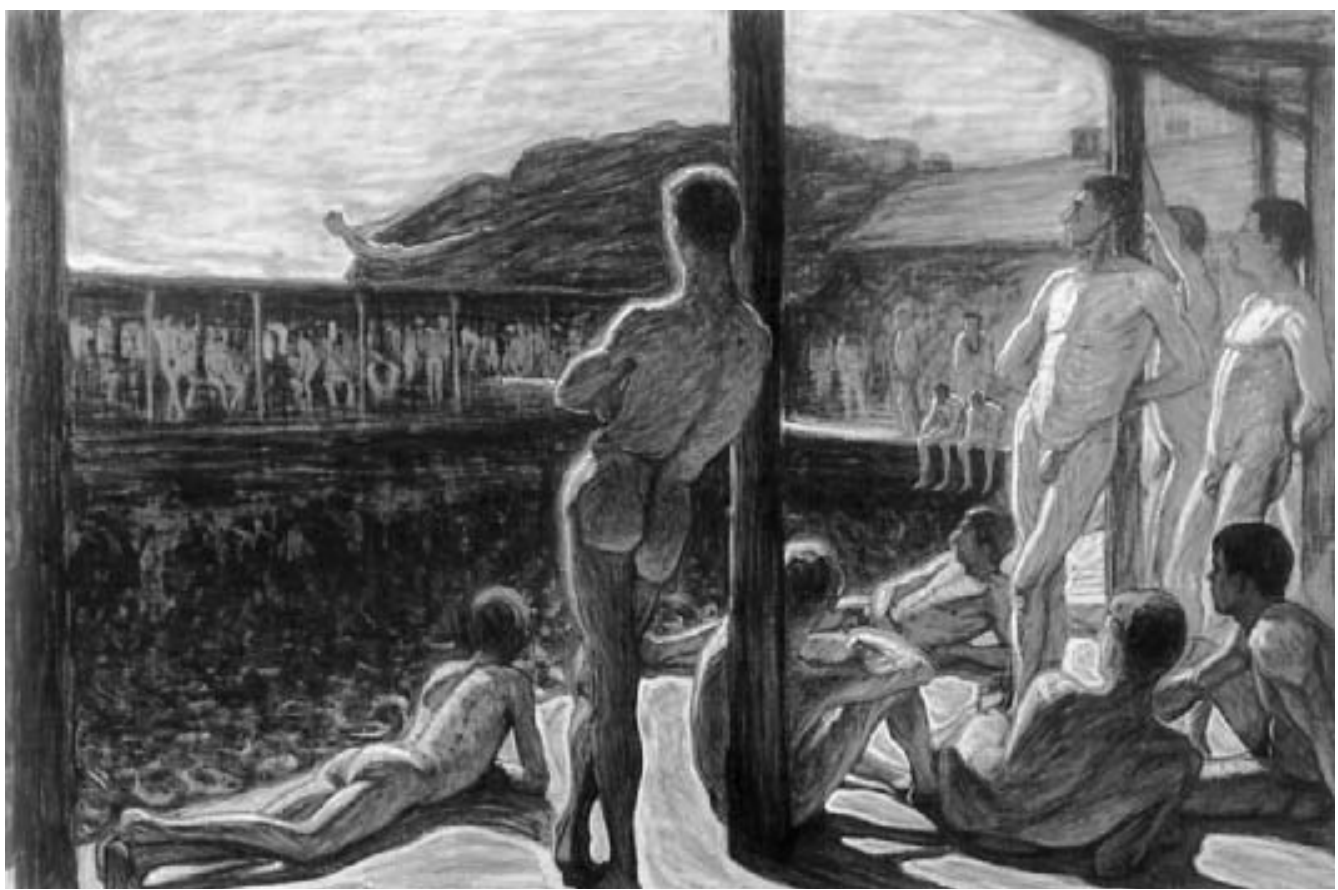

Flottans badhus, 1907. Ølja, $197 \times 301$ cm. (Thielska Galleriet. Foto Sven Nilsson).

ham. Det var med andre ord en udpræget krops-connesseur, der nu trådte i karakter.

Det sker med fuld styrke. Vistnok 1906 (dateringen er usikker) maler han sit første nøgenstudie: en ung mand, kraftigt bygget med en tatovering på venstre underarm. Her er ingen kosmiske overtoner, intet friskluft-livsevangelium.

Billedet ligner i sin realistiske detaljerigdom nærmere en illustration fra en lægebog. Det er et højst nøgternt og meget lidt sværmerisk maleri, beskueren står overfor. Det eneste, som vidner om fortiden er, at Janssons forkærlighed for de skumringsdystre farver fortsat dominerer. Men ellers er billedet kendetegnet af en påfaldende illusionsløshed. Det eneste, vi skal se, er et nøgent mandslegeme. Hverken mere eller mindre.

Året efter maler han sit måske mest berømte maleri fra den vitalistiske anden peri- ode: det store (ca. 2 × 3 m) maleri med titlen Flottans badhus. Nu kommer idrætten ind i billedet. Og her er forgrunden helt udfyldt; virkelighedens her-og-nu trænger sig på. Den domineres af solbeskinnede, velbyggede ynglinge, der alle opmærksomt vender blikket mod det, som er billedets motiviske centrum, nemlig udspringeren, der som en pil svæver over bassinets vand, i en sportsligt korrekt stilstudie. Han har som fond dels den blå himmel, dels en grønblå trægruppe og skærer sig ind over grænsen mellem disse to flader. I baggrunden en kæmpeflok af beundrende tilskuere. Kompositorisk er billedet bygget op af kraftige horisontale og vertikale linjer, hvor badehuslandskabets muligheder i form af dels vandlinjer, dels pavillonens træstøttepæle er udnyttet effektfuldt som indramning af et kraftparallellogram. Farvemæssigt opereres der med en lignende kontrast mellem 
den stærke, varme sol og den blå kølighed i vand og himmel. Tilværelsen er her ikke elegisk, men dynamisk og spændingsfyldt. Jansson skildrer den som en hård negl, håndværksmæssigt og nøgternt.

Året efter tager han atter badehusmotivet op til behandling. I maleriet Badtavla. Her er perspektivet vendt halvvejs. Vi ser denne gang udspringeren forfra, i stedet for fra siden. Men han svæver fortsat over vandene. Denne gang som en slags mellemting mellem en fugl og en flyvemaskine. Men han udgør stadig det fortættede midtpunkt, som alle retter blikket mod, og i forgrunden ser vi også denne gang de muskelstærke unge mænd med vaskebrætmaver, kønsorganer og kraftige skuldre. Også denne gang mere i samklang med en lærebog i humanbiologi end med et naturevangelium.

Endnu et vandbillede følger i 1911, Badsump. Her er vi nede i vandhøjde og ser de nøgne svømmere. Gulhvidt mod vandets blå. Sveriges nationalfarver, men uden direkte allusion til det nationalromantiske projekt. Den oscarianske punchepatriotisme med dens blanding af melankoli og vidtløftig gestik er her afløst af en ny tendens til friskhed og djærv forvovenhed. »Sverige« sidder nu ikke så meget i tanken som i bevægelsen; dvs. mere i kroppen end i sjælen. Vi er endelig kommet ind i det 20. århundrede, omend med en vis traditionsfastholdelse. Linjeføringen er stadig de rette vinkler med spænding mellem horisontale og vertikale linjer, mellem lav vandhøjde og robust opadstigen.

Fra 1912 ændrer han motiv. Nu rykker han indendøre og maler akrobater, brydere og vægtløftere. Vand-smidigheden erstattes af dyrkelsen af kraften med en stærk interesse for de kompositoriske muligheder i kroppenes parallellitet. De to brydere, der begge presser sig tungt ind mod hinanden, fordobler hinanden, på samme måde som akrobaterne gør det med den ene på gulvet og den anden i luften: deres arme og torsoer gentager hinanden spejlvendt. Det er kroppenes evne til kombinatorik og samklang, der nu er i centrum, medens eneren i form af vægtløfteren dog fortsat gør sig gældende. Jansson var altid en kontinuitetens mand midt i al nytænkning.

At alt dette nok har med en mere eller mindre erkendt homosexualitet at gøre (som datiden sladrede om) spiller ingen rolle i denne forbindelse. Det, der frister Jansson, er glæden ved at kunne male styrken og kompetencen i menneskekroppen. På den måde foregriber han det idrætslige gennembrud, der finder sted samme år - i 1912 - hvor de olympiske lege afholdes i Stockhom. I strålende sol. »Solskinsolympiaden« blev den kaldt. Jansson må have bifaldet betegnelsen. Det ved vi imidlertid ingenting om. Her slår (jvf. ovenfor) ordene ikke til. Men malerierne er heldigvis meget-sigende. De foregriber det, som - på godt og ondt - skulle komme til fuld udfoldelse i mellemkrigstiden, og fuldbyrder samtidig det, der havde været undervejs til sig selv allerede i Bruno Liljefors' malerier fra 1880'erne.

\section{Kropskultur og tidsånd}

Allerede i 1880 'erne var den kendte svenske dyre- og naturmaler Bruno Liljefors begyndt at tage hul på treklangen: natur, kunst, idræt. Med sin veltrænede krop kunne han fungere som model for de andre elever ved Konstakademiets principskole (Ellenius 1997: 52). Han illustrerede flittigt samtidens idrætslitteratur, samtidig med at han selv dyrkede idræt. Især boksning og reck-gymnastik havde hans interesse, ligesom han langt op i årene dagligt gjorde gymnastik. I hans atelier stod der en barre (Örsan 1994: 132). 
Men Liljefors dannede aldrig rigtigt skole. Kun få nordiske kunstnere fulgte $\mathrm{i}$ hans fodspor. Harald Giersings berømte maleri Sophus header er ét eksempel, Jens Søndergaards maleri af en fodboldkamp i Thy et andet. Et af de seneste udslag var den udstilling med titlen Sports in Art, der sommeren 1995 blev vist på Konsthallen $\mathrm{i}$ Göteborg i tilslutning til VM i atletik sammesteds. Som helhed er kunsten og idrætten gået hver sin vej.

Men som vi har set, er der dog enkelte kunstnere, som har fattet interesse for idrættens, legens og friluftslivets dynamik. Blandt dem er der her valgt fire ud, som har det til fælles, at de laver deres mest kendte kropsmalerier i tidehvervet mellem det sene 1800-tals melankolske dekadence-opfattelse og det tidlige 1900-tals lyslevende optimisme, dvs. den periode hvor også idrætten for alvor slog igennem. Denne kobling mellem natur, kunst og idræt sker ikke over en nat - snarere er der tale om et længerevarende, evolutionært forløb. De har endvidere det til fælles, at idrætsbillederne også i kunstnernes egen livshistorie markerer en overgangsfase fra krise og tristesse til livsmod og fornyet styrke.

Det kan være svært at danne sig en endegyldig forståelse af, hvilke særlige træk ved idrætten, som fascinerede kunstnerne. Men måske finder man en forklaring hos Bruno Liljefors, når han peger på relationen mellem ro og stilstand, som glider over i fart, dynamik og djærv dåd:

»Vad jag njuter av $i$ en flygande trapets är den lugna följdriktiga harmoni som presteras, som med konsekvens följer in $i$ de djärvaste lägen, genom kropparnas fullkomlighet och akrobatens orubbliga precision i den lek han kan kosta på sig “ (Her cit. fra Ellenius 1997: 54).
Denne opfattelse, som på sin vis i bevægelsens egen tavse viden måske også illustrerer og fortolker overgangen mellem de stille 1890'ere og de livfulde år mellem 1900 og 1914, er Liljefors ikke ene om. Kropshistorikeren August Nitschke er inde på samme tanke, når han i sin bog Körper in Bewegung omtaler datidens store interesse for bevægelser, der forbinder to poler som fx. modsætningen mellem ind- og udånding, hæve og sænke etc. (Nitschke 1989: 325). Det ser med andre ord ud som om, at både idrætten og malerkunsten er en del af en samlet kollektiv mentalitet i den spændingsfyldte epoke mellem forfald og opblomstring, der kendetegnede disse år.

\section{Kroppen i form}

Når man betragter Janssons billeder, er det da også svært at se bort fra et indtryk af, at noget nyt er slået endeligt igennem. Det er ikke længere den demonstrative præsentation af den nøgne og karske mandskrop som hos Edvard Munch, der interesserer; ej heller de glade stranddrenge som hos Magnus Enckell, der bare er glade for at være til. Der er også langt til Willumsens patetiske, kosmisk orienterede naturskræk og til hans semiotiske interesse for mening og betydningsdannelse. Jansson er mindre højtidelig end Munch og Willumsen, men også mere motivisk forpligtet end Enckell. Han er repræsentanten for sportens væsen. Kraften sættes i system og udformes nu langt mindre Nietzscheansk og martialsk end den her-kommer-jeg/kan-alle-se-migholdning, der strålede ud af Munchs nøgne bademænd. Samtidig med dette er det tydeligt, at det lyse legeelement, der prægede Enckells »vandhunde«, her hvor vi har med sport at gøre, organiseres og regelsættes med koder og kontrolleret præstation. På den måde bidrager malerne omkring 
1910 også til en indkredsning af den kropsudfoldelse, der skulle komme til at tegne billedet i løbet af det 20. århundrede: idrætten mellem blodig alvor og lys leg, mellem vitalistisk superman-isme og relationelt, fredeligt kropssamarbejde.

Således er der betydelige forskelle mellem de fire opfattelser af kroppen og dens væsen. Men samtidig er der også en fundamental lighed i kraft af den begejstret-nysgerrige, men også frygtsomt-dragende fascination af kropsligheden og dens nye fremtræden på scenen - som vi så det hos Marie Bregendahl - der er så kendetegnende for de første par tiår af det 20. århundrede, hvor det biologiske og det kunstneriske tager livtag med hinanden.

\section{Litteratur}

Marie Bregendahl, »Sommeraften« I: De lyse Natter (København, 1920).

Lise Buurgaard, J. F. Willumsen. Bjerget, kvinden, selvet (Esbjerg, 1997).

Henrik Cornell, Den svenska konstens historia. Från nyantiken till Konstnärsförbundet (Stockholm, 1959).

Arne Eggum, Edvard Munch. Malerier - skitser og studier (København 1983)

Allan Ellenius, Bruno Liljefors. Naturen som livsrum (Stockholm, 1996).

Sigurd Frosterus, Olikartade skönhetsvärden (Stockholm og Borgå, 1915).

Sigurd Frosterus, Nordiskt $i$ dur och moll (Helsingfors, 1946).

Liisa Kasvio, »Den unge samlarens stämningar - värderingar utformas, samlingen blir till« I: Sigurd Frosterus' samling (Helsingfors, 1992). Amos Anderssons Konstmuseum (udg.).

Niels Kayser Nielsen, »Kritisk loyalitet - om kulturradikalisme i Norden« I: Värdetraditioner $i$ nordiskt perspektiv. Rapport från ett symposium $i$ Helsingfors, Göran Bexell og Henrik Stenius (red.) (Lund, 1997) Lund University Press.
Samtidig kan disse nordiske maleres fremstilling og indkredsning af krop, leg, idræt og friluftsliv være en påmindelse om, at idrætten også rummer en æstetisk dimension. Den synes at blive mere og mere glemt, i takt med at præstation og konkurrence har taget over og gjort idræt til afstumpet sport og stupid kommers. I de første sanseferske tiår af 1900-tallet var man imidlertid yderst bevidst om den æstetiske dimension - her drejede det sig om både sindets og kroppens opvågnen. Her bidrog litteraturen, idrætten og kunsten ligeligt til at præsentere de nye muligheder for kropslig dannelse og frigørelse, som stod på historiens tapet - og til at demonstrere en ny viden om kroppen og sanserne.

Leila Krogh, Lovens breve. J. F. Willumsens breve til Alice Krogh 1899-1923 (Frederikssund, 1987).

Leila Krogh, Fiktion og virkelighed. J. F. Willumsens fotografier (Frederikssund, 1995).

Peter Laugesen, Gallén-Kallela (København, 1992).

Sven-Eric Liedman, Mellan det triviala och det outsägliga. Blad ur humanioras och samhällsvetenskapernas historia (Göteborg, 1997).

Erik Moltesen, J. F. Willumsen. Introduktion til hans Kunst (København, 1923), Levin og Munksgaard. August Nitschke, Körper in Bewegung. Gesten, Tänze und Räume im Wandel der Geschicht (Stuttgart, 1996).

Jacob Paludan, »Især om Tonio Krøger« I: Tonio Krøger (København, s. a.).

Ragna Stang, Mennesket og kunstneren Edvard Munch (København, 1978).

Inga Zachau, »Eugène Jansson. Den blå stadens målare« I: Eugène Jansson, Katalog (Stockholm, 1998). Liljevalchs Konsthall (udg.).

Grete Zahle, Himlens spejl (København, 1994).

Karl Örsan, »Bruno Liljefors och idrotten« I: Idrott, historia och samhälle. Svenska idrottshistoriska föreningens årsskrift (1994). 